\title{
Financial communication to retirement fund members: a survey among trustees and member stakeholders
}

\author{
De la Rey van der Waldt and Gerbie van Heerden
}

\begin{abstract}
It is anticipated that this study will increase awareness of financial communication in the retirement fund industry in South Africa where illiteracy is of national concern and where current financial communication is often drenched with financial jargon and technicalities merely to ensure compliance Only nine percent of South Africa citizens who are members of retirement funds will be financially independent once they reach retirement age. The other 91 percent will be dependent on other means to supplement their monthly income after retirement. Little is known about the financial communication sent to retirement fund members. This article thus aims to contribute to the knowledge base of financial communication in the context of retirement funds and to the managerial practice of financial communication in a retirement fund context.

A survey was conducted to determine how trustees and members of retirement funds perceive financial communication. The aim of the survey was to compare trustee and stakeholder members' perceptions of the various channels of financial communication, preferences with regard to the above financial communication channels and the importance of the message content of financial communication sent to members.

The results show that both trustees and members of retirement funds regard benefit statements as the most important channel of communication. There is a statistically significant difference between how trustees and members of retirement funds view the use of printed information and group presentations to communicate financial information. Both groups indicated a preference for information on a quarterly basis as opposed to annual reports.

With regard to the content of financial communication, both members and trustees indicated that the most important information is the current value and performance of their investments. With regard to preferred financial channels of communication, a statistically significant difference was found between how trustees and members view access to the pension fund's call centre. A statistically significant difference was also found between how trustees and members believe the pension fund should work.

This study attempts to make a contribution to financial communication within the context of the retirement fund industry in South Africa. It is necessary for fund trustees (management) to reconsider their traditional use of communication channels to inform fund members (stakeholders). with legislation. Clear, understandable and unambiguous information content should be reflected in financial communication to trustees and member stakeholders.
\end{abstract}

Keywords: retirement fund, pension fund, financial information, financial communication, stakeholders, trustees. 


\section{ORIENTATION}

Although there are more than 13000 retirement funds in South Africa with approximately 10 million members, only 9 percent of these members will make sufficient provision for their retirement (Van der Merwe 2004, 3) and will be able to retire independently one day. The other 91 percent will have to lower their standard of living considerably, work for longer (which is not always possible as many businesses are lowering their retirement age) or depend on their families or the state for financial assistance. Comprehensive, understandable financial information about retirement benefits can assist members to make adequate financial provision for their retirement.

Section 7D of the Pension Funds Act (Act 24 of 1956) states that one of the primary objectives of a retirement fund's board of trustees (management committee) is to ensure that sufficient and appropriate information is supplied to the members of the fund. Members of retirement funds should be informed of their rights, benefits and obligations in terms of the rules of the fund (Grobler 2004, 9). Soobramoney $(2004,13)$ argues that trustees must avoid superficial and thoughtless communication that is full of jargon and technicalities merely to ensure compliance with the relevant legislation, as this could result in ineffective communication. According to Cingo $(2004,55)$, one of the most neglected elements of retirement fund management is effective communication with members.

\section{LITERATURE REVIEW}

\subsection{Financial communication}

Financial public relations is the dissemination of information that affects the understanding of stockholders and investors concerning the financial position and prospects of a company, and includes among its objectives the improvement of relations between companies and their stockholders (Cutlip, Center and Broom 1994, 176). This relatively new concept of financial communication, which has grown out of a broad view of financial public relations, has been researched in terms of investor relations by Dolphin (2004) and with regard to financial stakeholders by Colbert (2002) and Gay, Schelluch and Baines (1998). Colbert $(2002,148)$ distinguishes between different financial communication requirements when dealing with internal and external auditors, while Cutlip et al. (1994) and Du Plessis (2002, 59) highlight communication with shareholders. Buchner $(1994,231)$ defines financial public relations as the science of communicating 
with specific target audiences about a company's trading activities, financial status, strategy and values in order for them to accurately evaluate their investments. Since the concept of financial communication is relatively new and the literature related to it inadequate, a sound definition is problematic.

This article, however, focuses mainly on the perceptions of experts (retirement fund trustees) and laypeople (retirement fund members) with regard to their retirement fund communication. The following definition by Schoonraad $(2003,8)$ is applicable and relevant to this article's objectives: 'The establishment and maintenance of mutually beneficial relationships between a company and its relevant stakeholders, by exchanging information that is needed to facilitate optimal decisions regarding the allocation of scarce resources.'

\subsection{Research on retirement funds}

Research on retirement funds covers various sub-fields. Storey and Easingwood (1996) and Anon (2003) focus on service experience and perceptions of products, while Freitag and Picherit-Duthler (2004) focus on the so-called benefits communication, which includes medical aid/health and retirement benefits as part of the internal or employee communication function.

Earlier studies, which are applicable to the retirement fund industry, relate to service to the customer. Here, the gap that may exist between the expectations created and the actual service delivery could be crucial to the perception of service quality (Zeithaml, Berry and Parasuraman 1988, 45). Madden and Perry $(2003,119)$ assert that effective communication between the service provider and the customers/stakeholders is critical in order to influence the customers' buying decisions. One of the observations made by Lievens, Moenaert and S'Jegers (1999, 32) is that external communications affect customer expectations. They contend that external communication has a huge effect on new service success and that the quality of external communication, that is, the information that flows between the bank and its customers or potential customers, has to create awareness among potential users and create realistic expectations.

According to Nyce (2005, 2), financial communication must benefit the recipients thereof. In other words, it must help them to make informed financial decisions. Firms which make extensive use of financial communication report higher levels of feedback from their customers and increased participation in decision-making processes. He further states that effective financial communication plans are necessary to enable customers to plan 
effectively for their retirement $(2005,14)$.

Claycomb and Martin (2002, 620) suggest that most service providers believe in frequency of communication; it is clear that those service providers which communicate with their customers on a regular basis have a greater chance than their competitors of being remembered by their customers. In a survey undertaken by Claycomb and Martin (2002), 50 percent of the respondents indicated that continuous contact with clients is an essential part of building relationships. This contact may take the form of personal or nonpersonal contact, such as newsletters, letters, direct mailings and telephone calls, or customer visits, trade shows and conferences. Many of the service providers who participated in the study believe that the effectiveness of communication is enhanced when the process is interactive. Although personal contact normally results in dialogue, newsletters, advertisements, direct mail or the company website may encourage customers to make contact (Claycomb and Martin 2002, 622).

Madden and Perry $(2003,113)$ conducted research in Australia that focused on how customers of a financial services institution perceived communication. It emerged that participants perceive straightforward communication as helpful, as it assists them to make informed decisions.

\subsection{Two types of retirement funds}

There are two distinct types of retirements funds within the South African landscape: (1) the defined contribution fund, and (2) the defined benefit scheme.

\subsubsection{The defined contribution fund}

Approximately 70 percent of South African retirement funds have a defined contribution structure; members of these funds do not have the luxury of a guaranteed, lifelong pension payment (Van der Merwe 2004; Khojane 2004) as is the case with a defined benefit fund. These individuals live with the risk that they might not be able to retire with enough savings to sustain them through their retirement. In a defined contribution scheme, the investment risk is moved to the member/investor. Here, the risk entails that a member may lose a substantial amount of his or her retirement savings should investment markets perform poorly.

At retirement, a person will receive the sum of member and employer contributions, plus the growth obtained from this investment in the equity markets. Asset management and administration fees and tax, which have to be deducted, also have an impact on the benefit the member receives at retirement. 


\subsubsection{The benefit scheme}

The other 30 percent of retirement fund members belong to a defined benefit scheme. A defined benefit scheme guarantees a monthly amount for a lifetime. This monthly payment is a fixed amount. The defined contribution scheme pays the members' equitable share in the fund with which they have to buy a monthly retirement income, such as a retirement annuity. This is not a guaranteed amount and could be depleted prematurely depending on the percentage elected as a monthly income. The risk is moved from the retirement fund to the member as the investment is market related and there is an equitable share of profit.

Two separate circulars from the Financial Services Board act as the official guidelines to trustees with regard to financial communication to fund members. These include Circular No. 86 (PF86) and Financial Services Board, Circular No. 98 (PF98) of 2001. The PF86 (2001, 2) specifies that withdrawal options must be explained to a member in terms of the fund rules when such a member resigns, or if the member is retrenched or retires. It also stipulates that the investment in terms of a defined contribution fund must be explained. According to Soobramoney $(2004,13)$, the mere stipulation of these rules is not sufficient to help members make informed decisions about their retirement funds. Aspects such as the type of information and the financial communication channels are neglected in these circulars. It is uncertain if stakeholders are reached through the existing channels of communication and if they read all the information as presented in circulars. Ideally, the information should be explained in terms that laymen could understand and interpret.

\subsection{Stakeholder perspective}

In order to better understand stakeholder management and to assist fund trustees to identify the members as a specific stakeholder group, it is imperative that the stakeholder perspective is addressed. Various authors point out that financial communication focuses on specific or key stakeholders. According to Andrew (1990, 22), financial public relations is communication with key groups such as shareholders, investment analysts, financial institutions or the financial press. Buchner (1994, 233235) cites a broader audience range, which includes customers, employees, pressure groups and the general public. This corresponds with the statements of Jones (1990, 272) and Askew (1997, 244) that modern organisations have responsibilities that go beyond legal obligations to shareholders. These responsibilities are towards stakeholders such as investors, creditors, employees, business contacts, the government, consumers and the community.

The King II Report (King Committee on Corporate Governance 2002, 97) classifies 
stakeholder groups as shareholders, providers (e.g. employees, suppliers or contractors), purchasers (e.g. customers) and the community (e.g. interest groups or nongovernmental organisations). Hunter $(2000,2)$ emphasises that an organisation's communication should be managed in such a way that stakeholders receive the communication they expect. Hunter $(2000,2)$ realises that this is idealistic, but states that it should be a goal.

One of the principles of stakeholder management emphasises that managers should listen to and openly communicate with stakeholders about respective concerns, contributions and the risks they assume because of their involvement with the corporation (The Clarkson Center for Business Ethics 2006, 151). The focus in this article is to look at trustees and members' attitudes towards financial communication.

\section{RESEARCH PROBLEM AND HYPOTHESES}

The problem encountered in this study is that little is known about financial communication within the context of the retirement fund industry. Are trustees and members of a retirement fund informed by the same communication channels? Do they prefer the same financial communication channels? Do trustees and members of retirement funds have different views on the importance of financial communication content? Moreover, little research has been done on financial communication with retirement fund members within the South African context, as reflected by the following journal platforms: Emerald, EbscoHost and Science Direct.

The purpose of this article is to determine whether trustees and retirement fund members have different views on the channels used to disseminate financial communication, their preferences with regard to the above financial communication channels and their views on the importance of the message content of financial communication.

$\mathrm{H}_{1}$ : Trustees and members do not differ with regard to the communication channel used to convey financial information.

$\mathrm{H}_{2}$ : Trustees and members do not differ with regard to the preferred channels of financial communication.

$\mathrm{H}_{3}$ : Trustees and members do not differ on the importance of the financial communication content.

\section{RESEARCH METHOD}

A self-administrated e-mail survey (Cooper and Schindler 2006, 285) was conducted 
among trustees (management) and members (stakeholders) of an umbrella fund in order to identify the financial communication channels used in the above context.

\subsection{Sampling}

A well-known umbrella retirement fund was selected for the purposes of this article. This retirement fund was selected because one of the authors is an employee at the fund. The authors thus had authorised access to the sample frame and were permitted to use the information for academic purposes. An umbrella retirement fund is regarded as a fund that accommodates various employers. It is normally more cost-effective for small businesses to offer such a retirement fund to their employees than to set up a fund of their own. The members of the umbrella fund in this study are mainly situated in the Gauteng and KwaZulu-Natal regions, with a smaller number of members in Mpumalanga and the rest of the country. This fund was chosen because it is representative of the general composition of retirement funds in the country and because no other research has been conducted on this fund. The general composition of the fund replicates that of the average fund in the retirement fund industry with regard to literacy, income, benefits, and so on.

Two samples were drawn: one of the trustees and the other of the members of the pension fund. The probability sampling technique was used in the fund member sample, where each member of the population has a known non-zero chance of being selected (Cooper and Schindler 2006, 446). According to Zikmund (2003, 178), the problem of nonresponse error is prevalent in mail and Internet surveys.

\subsubsection{Trustee sample}

Two hundred trustees were identified at random through the Principal Officer's Association list. These trustees all received a questionnaire by e-mail. Only 26 trustees completed the questionnaire, which provides a response rate of 12.5 percent. Numerous follow-up calls were made to motivate trustees to complete the questionnaires, but to no avail. The final amount remained at $26(\mathrm{n}=26$ trustees).

\subsubsection{Fund member sample}

The umbrella fund has approximately 30 participating employers with a total membership of approximately 1800 individuals. The umbrella fund's complete membership list was used as the sampling frame. In order to make the research project feasible with regard to time and costs, it was decided to focus on those members who were literate and who were able to complete a printed or e-mail questionnaire. The literate members with a minimum 
qualification of metric reduced the number of individuals eligible for the study to 900 . Every second individual from the 900 identified members of the pension fund were selected to participate in the research (450 members.)

A non-response error (the statistical difference between a survey that includes only those who responded and a perfect survey that would also include those who failed to respond) also occurred in this survey, with a total of 86 retirement fund members responding to the questionnaire ( $\mathrm{n}=86$ members). This results in a 19.1 percent response rate for the retirement fund member sample.

\subsection{Questionnaire}

Both nominal and ordinal scales were used to measure the response. Clear and understandable questions are regarded as having face/content validity, for example: How often would members like to receive communication from their retirement fund? The study may be regarded as having validity, because the pre-test delivered almost the same results. Although low frequency values were encountered, due to a relatively low response rate, it is likely that the survey, if conducted again, would reveal the same consistent results.

Both the trustees and the members of the pension fund were asked five similar questions. The first question related to the use of the following communication channels for disseminating financial communication to both trustees and members: newsletters, benefit statements, member guides, fund brochures, videos, presentations, website information and written letters. The second question concerned the importance of receiving information through the above communication channels. The third question emphasised the content of the financial communication. Under this question, the following topics were relevant: fund rules, current fund value, savings, death benefits, disability benefits, the functioning of the fund, dependent benefits, investments, investment performance, management of the fund, fund information and complaints. The forth question involved the frequency of financial communication: monthly, quarterly, twice a year and annually. The fifth question concerned the preference of financial communication channels as indicated under the first question above. The above items were tested on a three-point Likert-type scale ranged from 1 ('not important') to 3 ('very important').

\subsection{Research procedure}

Pre-testing was done on three trustees and five fund members who were selected at random. They completed the questionnaires to determine the level of comprehension and 
to clarify any uncertainties in the questionnaire. Alterations were made for the final questionnaire.

The actual survey was conducted during the first week in November 2005. The personnel practitioners of the retirement fund helped to conduct the survey. Completed questionnaires were sent back to the researchers either by fax or e-mail. Some respondents sent their questionnaires via the personnel practitioners, who then forwarded them to the researchers.

\section{RESULTS}

\subsection{Descriptive statistics}

Retirement fund members received information through different financial communication channels. Some were exposed to the traditional mass media, while others only received financial information through the electronic media. A distinction was made between those who received information through a particular financial communication channel and those who did not receive information through that particular channel.

Table 1 below provides the results of the communication channels used by the respective retirement funds to provide retirement fund members with financial information.

The results in the above table could give management an indication of the communication needs of retirement fund members. It is significant that 100 percent of members rate benefit statements as important, irrespective of whether or not they currently receive this communication channel. While 61.97 percent of members do not receive a newsletter, 88.64 percent of them regard this as important. Of the 71.23 percent of members who do not receive a rule book, 98.08 percent regard it as important. It is noteworthy that 83.3 percent regard website information as important, despite the fact that 32.88 percent of the respondents do not have access to the Internet. 
Table 1: Communication channels to inform fund members $(n=86)$

\begin{tabular}{|c|c|c|c|c|}
\hline Communication channel & Access & Not important & $\begin{array}{l}\text { Important } \\
\text { to receive }\end{array}$ & Total \\
\hline \multirow[t]{2}{*}{ Newsletters } & Receive & $\begin{array}{l}0 \\
0.00 \%\end{array}$ & $\begin{array}{l}27 \\
100.00 \%\end{array}$ & $\begin{array}{l}27 \\
38.03 \%\end{array}$ \\
\hline & Do not receive & \begin{tabular}{|l|}
5 \\
$11.36 \%$ \\
\end{tabular} & $\begin{array}{l}39 \\
88.64 \% \\
\end{array}$ & \begin{tabular}{|l|}
44 \\
$61.97 \%$ \\
\end{tabular} \\
\hline \multirow[t]{2}{*}{ Benefit statements } & Receive & $\begin{array}{l}0 \\
0.00 \%\end{array}$ & $\begin{array}{l}69 \\
100.00 \%\end{array}$ & $\begin{array}{l}69 \\
87.34 \%\end{array}$ \\
\hline & Do not receive & $\begin{array}{l}0 \\
0.00 \%\end{array}$ & $\begin{array}{l}10 \\
100.00 \%\end{array}$ & $\begin{array}{l}10 \\
12.66 \%\end{array}$ \\
\hline \multirow[t]{2}{*}{ Member guides/rule books } & Receive & \begin{tabular}{|l|}
0 \\
$0.00 \%$ \\
\end{tabular} & $\begin{array}{l}21 \\
100.00 \% \\
\end{array}$ & \begin{tabular}{|l|}
21 \\
$28.77 \%$ \\
\end{tabular} \\
\hline & Do not receive & $\begin{array}{l}1 \\
1.92 \% \\
\end{array}$ & $\begin{array}{l}51 \\
98.08 \%\end{array}$ & $\begin{array}{l}52 \\
71.23 \% \\
\end{array}$ \\
\hline \multirow[t]{2}{*}{ Fund brochures } & Receive & \begin{tabular}{|l|}
3 \\
$12.50 \%$ \\
\end{tabular} & $\begin{array}{l}21 \\
87.50 \% \\
\end{array}$ & \begin{tabular}{|l}
24 \\
$33.80 \%$ \\
\end{tabular} \\
\hline & Do not receive & \begin{tabular}{|l|}
5 \\
$10.64 \%$ \\
\end{tabular} & $\begin{array}{l}42 \\
89.36 \% \\
\end{array}$ & $\begin{array}{l}47 \\
66.20 \% \\
\end{array}$ \\
\hline \multirow[t]{2}{*}{ Induction/fund videos } & Receive & \begin{tabular}{|l|}
2 \\
$25.00 \%$ \\
\end{tabular} & $\begin{array}{l}6 \\
75.00 \% \\
\end{array}$ & \begin{tabular}{|l|}
8 \\
$11.76 \%$ \\
\end{tabular} \\
\hline & Do not receive & \begin{tabular}{|l|}
27 \\
$45 \%$ \\
\end{tabular} & $\begin{array}{l}33 \\
55.00 \% \\
\end{array}$ & \begin{tabular}{|l}
60 \\
$88.24 \%$ \\
\end{tabular} \\
\hline \multirow[t]{2}{*}{ Presentations } & Receive & \begin{tabular}{|l|}
5 \\
$25.00 \%$ \\
\end{tabular} & $\begin{array}{l}15 \\
75.00 \% \\
\end{array}$ & \begin{tabular}{|l|}
20 \\
$29.41 \%$ \\
\end{tabular} \\
\hline & Do not receive & \begin{tabular}{|l|}
17 \\
$35.42 \%$ \\
\end{tabular} & $\begin{array}{l}31 \\
64.58 \% \\
\end{array}$ & \begin{tabular}{|l}
48 \\
$70.59 \%$ \\
\end{tabular} \\
\hline \multirow[t]{2}{*}{ Call centres } & Receive & $\begin{array}{l}2 \\
4.17 \% \\
\end{array}$ & $\begin{array}{l}46 \\
95.83 \%\end{array}$ & $\begin{array}{l}48 \\
69.57 \% \\
\end{array}$ \\
\hline & Do not receive & $\begin{array}{l}2 \\
9.52 \%\end{array}$ & $\begin{array}{l}19 \\
90.48 \%\end{array}$ & $\begin{array}{l}21 \\
30.43 \%\end{array}$ \\
\hline \multirow[t]{2}{*}{ Website information } & Receive & \begin{tabular}{|l}
3 \\
$6.12 \%$ \\
\end{tabular} & $\begin{array}{l}46 \\
93.88 \% \\
\end{array}$ & \begin{tabular}{|l}
49 \\
$67.12 \%$ \\
\end{tabular} \\
\hline & Do not receive & \begin{tabular}{|l|}
4 \\
$16.67 \%$ \\
\end{tabular} & $\begin{array}{l}20 \\
83.33 \% \\
\end{array}$ & $\begin{array}{l}24 \\
32.88 \% \\
\end{array}$ \\
\hline \multirow[t]{2}{*}{ Letters } & Receive & \begin{tabular}{|l}
5 \\
$20.00 \%$
\end{tabular} & $\begin{array}{l}20 \\
80.00 \%\end{array}$ & $\begin{array}{l}25 \\
36.23 \%\end{array}$ \\
\hline & Do not receive & \begin{tabular}{|l|}
9 \\
$20.45 \%$
\end{tabular} & $\begin{array}{l}35 \\
79.55 \%\end{array}$ & $\begin{array}{l}44 \\
63.77 \%\end{array}$ \\
\hline
\end{tabular}


Table 2 below reflects the preferred frequency of the financial communication to both members and trustees.

Table 2: Preferred frequency of financial communication

\begin{tabular}{|l|l|l|}
\hline Frequency & $\begin{array}{l}\text { Members \% } \\
\mathbf{n = 8 5}\end{array}$ & $\begin{array}{l}\text { Trustees\% } \\
\mathbf{n}=\mathbf{2 6}\end{array}$ \\
\hline Monthly & $16.47(14)$ & $7.69(2)$ \\
\hline Quarterly & $56.47(48)$ & $73.08(19)$ \\
\hline Twice a year & $21.18(18)$ & $15.38(4)$ \\
\hline Annually & $5.88(5)$ & $3.85(1)$ \\
\hline
\end{tabular}

The majority of respondents indicated that they prefer quarterly communication. In the study, 73.08 percent of the trustees thought retirement funds should communicate with members on a quarterly basis, while 56.47 percent of members indicated that they would like to receive communication quarterly. A total of 15.38 of the trustees indicated that they would like to receive communication twice a year, while 21.18 percent of members indicated this preference. A total of 16.47 percent of members indicated that they would like to receive monthly communications, while 5.88 percent thought that annual communication was sufficient. A total of 7.69 percent of trustees thought that communication should be sent out to members on a monthly basis, while 3.85 percent of trustees indicated a preference for annual communication.

Table 3 below indicates the differences between members and trustees with regard to the hierarchy of importance attached to financial communication content. It is listed from the most important to the least important topic.

The above topics were compiled and summarised at random from newsletters that were sent to members and trustees during 2005. The above table reflects that members and trustees view the current retirement fund value as the most important piece of information, which also correlates with the benefit statement variable (which includes fund value/fund credit). The performance of investment portfolios and the amount of money at retirement are also important aspects.

Notable differences occurred in terms of information that explains how the pension fund works (members: $72.94 \%$ as opposed to trustees: $46.15 \%$ ). Member perceptions of the management of their pension fund are high on importance (68.50\%o), while trustees view it as moderately important $(50.00 \%$ o).

\subsection{Hypothesis testing}

$\mathrm{H}_{1}$ : Trustees and members do not differ with regard to the communication channel used to convey financial information. 
Table 3: Financial communication content - hierarchy of importance

\begin{tabular}{|l|l|l|}
\hline \multirow{2}{*}{ Financial communication content on the topics below } & \multicolumn{3}{l|}{ Very important - frequency } \\
\cline { 2 - 3 } & $\begin{array}{l}\text { Members \% } \\
\mathbf{n}=\mathbf{8 6}\end{array}$ & $\begin{array}{l}\text { Trustees \% } \\
\mathbf{n}=\mathbf{2 6}\end{array}$ \\
\hline Current fund value & $92.94(79)$ & $92.31(24)$ \\
\hline Performance of my investments & $88.24(75)$ & $88.46(23)$ \\
\hline Fund value at retirement & $86.05(74)$ & $84.62(22)$ \\
\hline Disability benefits & $84.88(73)$ & $73.08(19)$ \\
\hline Am I saving enough? & $82.35(70)$ & $84.62(22)$ \\
\hline Will my dependents be looked after? & $82.35(70)$ & $80.77(21)$ \\
\hline How will my investments work? & $80.23(69)$ & $72.00(18)$ \\
\hline Death benefits & $80.00(68)$ & $73.08(19)$ \\
\hline How my fund works & $72.94(62)$ & $46.15(12)$ \\
\hline Where I can obtain fund information & $70.59(60)$ & $73.08(19)$ \\
\hline Management of the fund & $68.60(59)$ & $50.00(13)$ \\
\hline Where can I lodge a complaint? & $61.18(52)$ & $61.54(16)$ \\
\hline Fund rules & $57.14(48)$ & $52.00(13)$ \\
\hline
\end{tabular}

Table 4 below reflects the response by both members and trustees on the format of financial communication.

Table 4: Channels of financial communication

\begin{tabular}{|l|l|l|l|l|l|}
\hline Format & $\begin{array}{l}\text { Members } \\
\mathbf{n = 8 6}\end{array}$ & $\begin{array}{l}\text { Trustees } \\
\mathbf{n = 2 6}\end{array}$ & Total & $\mathbf{N}$ & p-value \\
\hline Printed information & 58 & 23 & 81 & 105 & $0.04^{*}$ \\
\hline Electronic information & 71.60 & 28.40 & 77.14 & & \\
\hline One-on-one consultations & 67 & 23 & 90 & 98 & 0.97 \\
& 74.44 & 25.56 & 91.84 & & \\
\hline Group presentations & 36 & 13 & 49 & 96 & 0.39 \\
\hline Speak to call centre personnel & 73.47 & 26.53 & 51.04 & & \\
\hline Video & 43 & 19 & 62 & 94 & $0.02^{*}$ \\
& 69.35 & 30.65 & 65.96 & & \\
\hline & 72.73 & 27.27 & 58 & 94 & 0.45 \\
\hline & 18 & 6 & 24 & 85 & 0.36 \\
\hline
\end{tabular}

* Significant statistical difference $(p<0.05)$ 
Of the 77.14 percent respondents who showed a preference for printed information, 71.6 percent were members and 28.4 percent trustees. Of the 91.84 percent respondents who indicated a preference for electronic information, 73.47 percent comprised members and 26.53 percent trustees. A total of 73.47 percent of all the members who responded indicated a preference for one-on-one consultations, while 69.35 percent indicated a preference for group presentations. Members and trustees showed a low preference for video communication. This hypothesis was tested using a two-sample Chi-Square test with a two percent level of independence $(a=0.05)$. Looking at the probability value of the variables pertaining to printed information $(\mathrm{p}=0.04)$ and group presentations $(\mathrm{p}=$ 0.02), the null hypothesis was rejected.

$\mathrm{H}_{2}$ : Trustees and members do not differ with regard to the preferred channels of financial communication.

Table 5 below reflects the differences between trustees and members with regard to the preferred channels of communication.

Table 5: Trustee and member reactions on the preferred communication channel

\begin{tabular}{|l|l|l|l|l|l|l|l|}
\hline Communication channel & \multicolumn{3}{l}{$\begin{array}{l}\text { Members } \\
\mathbf{n = 8 6}\end{array}$} & \multicolumn{2}{l}{$\begin{array}{l}\text { Trustees } \\
\mathbf{n}=\mathbf{2 6}\end{array}$} & \\
\hline & Mean & SD & $\mathbf{n}$ & Mean & SD & $\mathbf{n}$ & p-value \\
\hline Newsletters & 2.25 & 0.56 & 81 & 2.26 & 0.53 & 26 & 0.97 \\
\hline Benefit statements & 2.89 & 0.31 & 83 & 2.92 & 0.27 & 26 & 0.64 \\
\hline Member guides/rule books & 2.53 & 0.52 & 82 & 2.34 & 0.48 & 26 & 0.08 \\
\hline Fund brochures & 2.14 & 0.66 & 82 & 2.00 & 0.63 & 26 & 0.31 \\
\hline Induction/fund videos & 1.70 & 0.77 & 80 & 1.96 & 0.77 & 26 & 0.12 \\
\hline Presentations & 1.97 & 0.85 & 78 & 2.11 & 0.51 & 26 & 0.43 \\
\hline Access to call centre & 2.51 & 0.63 & 81 & 2.15 & 0.78 & 26 & $0.02 *$ \\
\hline Website information & 2.52 & 0.65 & 82 & 2.38 & 0.69 & 26 & 0.32 \\
\hline Letters & 2.02 & 0.69 & 79 & 2.15 & 0.61 & 26 & 0.41 \\
\hline Face-to-face consultations & 1.94 & 0.77 & 83 & 2.15 & 0.78 & 26 & 0.22 \\
\hline
\end{tabular}

* Significant statistical difference $(p<0.05)$

This hypothesis was tested using the Mann-Whitney U test (ordinal scale) with a 5 percent level of measurement $(\mathrm{a}=0.05)$ indicating differences in variables. The hypothesis can only be rejected in terms of the variable regarding access to a call centre; the alternative 
hypothesis is thus supported in this instance. The results of the research show that 32.10 percent of members and 30.77 percent of trustees place value in a newsletter, whereas 92.31 percent of trustees and 89.16 percent of members believe in the importance of a benefit statement. The benefit statement is viewed as the most important variable recorded.

A rule book or member guide was regarded as very important by 54.88 percent of members and 34.62 percent of trustees. Only 19.23 percent of trustees regarded retirement fund presentations for members as very important, while 34.62 percent of members indicated it was very important to them. Access to a call centre for members was regarded as very important by 59.26 percent of members and 38.46 percent of trustees. Access to a website was very important to 60.98 percent of trustees and 50 percent of members. A total of 26.51 percent of members thought face-to-face consultations were very important, while 38.36 percent of trustees regarded consultations as important to members. With regard to access to the call centre, there was a significant statistical difference $(p=0.02)$. The null hypothesis with regard to the other items in the table is rejected.

$\mathrm{H}_{3}$ : Trustees and members do not differ on the importance of the financial communication content.

Table 6 below indicates the response of members and trustees with regard to the importance of financial communication.

Table 6: Importance of financial communication content

\begin{tabular}{|c|c|c|c|c|c|}
\hline \multirow[t]{2}{*}{ Financial communication content } & \multicolumn{2}{|c|}{$\begin{array}{l}\text { Members } \\
n=86\end{array}$} & \multicolumn{2}{|c|}{$\begin{array}{l}\text { Trustees } \\
n=26\end{array}$} & \multirow[t]{2}{*}{$p$-value } \\
\hline & Mean & SD & Mean & SD & \\
\hline Fund rules & 2.51 & 0.61 & 2.48 & 0.58 & 0.73 \\
\hline Current fund value & 2.90 & 0.36 & 2.92 & 0.27 & 0.93 \\
\hline Fund value at retirement & 2.83 & 0.36 & 2.80 & 0.49 & 0.83 \\
\hline Am I saving enough? & 2.80 & 0.45 & 2.84 & 0.36 & 0.75 \\
\hline Death benefits & 2.76 & 0.50 & 2.73 & 0.45 & 0.52 \\
\hline Disability benefits & 2.81 & 0.47 & 2.73 & 0.45 & 0.20 \\
\hline How my fund works & 2.69 & 0.53 & 2.42 & 0.57 & $0.01^{*}$ \\
\hline Will my dependents be looked after? & 2.77 & 0.52 & 2.77 & 0.51 & 0.87 \\
\hline How my investments work & 2.78 & 0.47 & 2.72 & 0.45 & 0.42 \\
\hline Performance of my investments & 2.85 & 0.41 & 2.88 & 0.32 & 0.94 \\
\hline Management of the fund & 2.64 & 0.57 & 2.46 & 0.58 & 0.10 \\
\hline Where can I obtain fund information? & 2.68 & 0.51 & 2.69 & 0.55 & 0.84 \\
\hline Where can I lodge a complaint? & 2.57 & 0.56 & 2.53 & 0.64 & .90 \\
\hline
\end{tabular}


This hypothesis was tested using the Mann-Whitney U test (ordinal scale) with a 5 percent level of measurement $(a=0.05)$ indicating differences in variables. The $p$-values suggest that the null hypothesis may only be rejected with regard to the variable of how my fund works $(\mathrm{p}=0.01)$. All the other variables support the hypothesis.

\section{LIMITATIONS}

As the study has been confined to one particular umbrella fund, the findings may be applied to individuals in this fund but cannot be generalised to all South African retirement funds.

A general trend of low response rates was found in this retirement fund context. The low response rates for both trustees and fund members resulted in validity warnings as various variables had cell counts of less than 5. Despite this, though, the findings are generally valuable as they emphasise gaps in financial communication with regard to the tested hypotheses in the retirement fund industry.

\section{CONCLUSION AND RECOMMENDATIONS}

The main objective of this research was to investigate financial communication channels and the content of financial communication in a retirement fund context. The hope is expressed that it will make a contribution to the body of knowledge on financial communication channels and information content within the retirement fund context in South Africa.

Results indicate a difference between the financial communication channels used by retirement funds to transmit information to members and the members' preferred channels of communication. Most members receive benefit statements and all members who answered this question regarded benefit statements as important.

Trustees should communicate financial communication through the preferred channels of communication in order to effectively reach the fund members. Two statistically significant differences were recorded with regard to the preferred channels of communication trustees and members would like members to receive: printed information and group presentations.

Two significant statistical differences were found between trustees and fund members with regard to their preferred channels of communication: group presentations $(p<0.02)$ and printed information $(\mathrm{p}<0.04)$. This might be because presentations provide trustees (management) with the opportunity to interact face-to-face with fund members (stakeholders), while printed communication is a convenient format in which to reach

large groups of fund members especially when those members do not have access to the Internet and e-mail information. 
Trustees and fund members did not differ significantly in terms of the communication channels used to inform members of retirement funds, except for access to a call centre, where a statistically significant difference was recorded $(\mathrm{p}<0.02)$. To fund members, this aspect was very important, while trustees regarded it as less important. This may be due to the fact that trustees may view human resources personnel as a resource for dealing with retirement fund queries, although they may not always be adequately trained to answer questions on financial communication.

The trustee and fund members both prefer to receive financial communication from their funds on a quarterly basis. Trustees and fund members generally did not differ with regards to the importance of the financial communication content that fund members of retirement funds should receive. A significant statistical difference occurred, however, on the item: how my fund works $(\mathrm{p}<0.01)$. This could be contributed to the notion that it is not indicated in the PF86 (2001) guidelines or that fund members have a greater need to understand fund matters than initially thought.

With regard to the hierarchy of importance of the financial communication content, fund members indicated that the current fund value, investment performance and fund value at retirement are important information variables. They are eager to receive more substance on these aspects. This hierarchy of financial communication content could give direction to a strategic communication plan for both retirement fund members and trustees. The financial communication needs of fund members may be seen as a driver for retirement fund information and content preferences. As an individual's retirement benefit is often the biggest investment he or she will make, it is necessary that fund members be informed about all the relevant issues about their retirement. Better decisions could be made before and after retirement, when fund members are adequately informed. Sound financial communication that is understandable, accurate and well-presented in 'layman's terms' should contribute to the mutually beneficial relationships between the organisation and its relevant stakeholders.

This article recommends that future research should focus on trustee (management) and fund members' (stakeholders) understanding of the financial communication, analyses of the financial communication needs of both trustees and fund members, and research on stakeholder relationship management in the retirement fund industry.

\section{References}

Andrew, A. 1990. The financial public relations handbook. New York: Woodhead-Faulkner. Anon, 2003. Pension fund administrators rated by corporate clients and trade unions. PMR July:18.

Askew, P. 1997. Stakeholderism in practice: A market-led view. Journal of Communication Management 2 (3):24-250.

Buchner, P. 1994. Financial public relations. In Public relations in South Africa: A management reader, ed. B. Lubbe and G. Puth. Durban: Butterworths. 
Cingo, W. 2004. Educating the fund member. IRFocus August:53-55.

Claycomb, C. and C. L. Martin. 2002. Building customer relationships: An inventory of service providers' objectives and practices. Journal of Services Marketing 16 (7):615-635.

Colbert, J. L. 2002. Corporate governance: Communications from internal and external auditors. Managerial Auditing Journal 17 (3):147-152.

Cooper, D. R. and P. S. Schindler. 2006. Business research methods. 9th ed. New York: McGraw-Hill.

Cutlip, S. M., A. H. Center and G. M. Broom. 1994. Effective public relations. 7th ed. New Jersey: Prentice-Hall.

Cutlip, S. M., A. H. Center, G. M. Broom and D. F. du Plessis. 2002. Essentials of effective public relations for sub-Saharan Africa. Cape Town: Pearson Education.

Dolphin, R. R. 2004. The strategic role of investor relations. Corporate Communications: An International Journal 9 (1):25-42.

EbscoHost. 2006. http://0ejournals.ebsco.com.innopac.up.ac.za/Home.asp/ (accessed 28 August 2006).

Emerald. 2006. http://0www.emeraldinsight.com.innopac.up.ac.za/ (accessed 10 October 2006).

Financial Services Board, Circular No. 86. 2001. General guidelines on boards of pension funds and other objects and duties. Financial Services Board, Pretoria, South Africa.

Financial Services Board, Circular No. 98. 2001. General guidelines on boards of pension funds and other objects and duties. Financial Services Board, Pretoria, South Africa.

Freitag, A. R. and G. Picherit-Duthler. 2004. Employee benefits communication: Proposing a PR-HR cooperative approach. Public Relations Review 30 (4):475-482.

Gay, G., P. Schelluch and A. Baines. 1998. Perceptions of messages conveyed by review and audit reports. Accounting, Auditing and Accountability Journal 11 (4):472-494.

Grobler, J. 2004. Comprehensive member communication: A trustee duty. IRFocus August:9-10.

Hunter, T. 2000. Integrated communications, stakeholders and stakeholder databases: New approaches to communication management. Akademija, MM 6 (June):1-6.

Jones, T. C. 1990. Corporate social accounting and the capitalist enterprise. In Critical accounts, ed. D. J. Cooper and T. M. Hopper. London: MacMillan.

Khojane, T. 2004. In defined contributions, workers must emulate investors. Business Report, 14 October:4.

King Committee on Corporate Governance. 2002. King Report II on Corporate Governance for South Africa 2002. Parklands: Institute of Directors for Southern Africa.

Lievens, A., R. K. Moenaert and R. S'Jegers. 1999. Linking communication to innovation success in the financial services industry: A case study analysis. International Journal of Service Industry Management 10 (1):23-47.

Madden, K. M. and C. Perry. 2003. How do customers of financial services institution judge its communications? Journal of Marketing Communications 9:113-127.

Nyce, S. A. 2005. The importance of financial communication for participation rates and contribution levels in 401(k) plans. Pension Research Council Working Paper, PRC WP 2005-3. Philadelphia: The Whatton School, University of Pennsylvania.

The Clarkson Center for Business Ethics. 2006. In Stakeholders: Theory and practice, ed. A. L. Friedman and S. Miles. Oxford: Oxford University Press.

Schoonraad, N. 2003. Managing financial communication: Towards a conceptual model. Unpublished M Com Dissertation, University of Pretoria. 
Science Direct. 2006.

http://0www.sciencedirect.com.innopac.up.ac.za/science?_ob=BrowseListURL\&type= subjectandsubjColl $=14$ andzone $=$ brwsand_acct $=\mathrm{C} 000005298 \&$ version $=1$ and_urlVersion $=$ 0and_userid $=59388$ andmd5 $=6$ dcfe4cc6b2 182 dfdade5ff066154ef0 (accessed 11 October 2006).

Soobramoney, C. 2004. Adding value to members. IRFocus August:12-14.

Storey, C. D. and C. J. Easingwood. 1996. Determinants of new product performance: A study in the financial services sector. International Journal of Service Industry Management 7 (1):32-55. Van der Merwe, E. 2004. Pension shame. Moneyweb 28 October:1-6.

Zeithaml, V. A., L. L. Berry and A. Parasuraman. 1988. Communication and control processes in the delivery of service quality. Journal of Marketing 52 (April):35-48.

Zikmund, W. G. 2003. Business research methods. 7th ed. Mason, Ohio: Thomson/South-Western. 